\title{
Protection AgAinst Slavery in NEW ZEALAND
}

Katja Heesterman*

The decision of the European Court of Human Rights in $\mathrm{CN} v$ The United Kingdom highlighted that slavery remains a modern problem. It may no longer resemble the traditional picture of slavery dramatically presented by Hollywood but it is no less an issue. Modern slavery is less visible; it is hidden away within homes, normal workplaces or in overseas factories. This article argues that New Zealand's current treatment of slavery is inadequate, exemplified by the absence of prosecutions. Thorough protection of slavery requires clear definitions that courts can easily apply. This article explores how the New Zealand Bill of Rights Act 1990 could be used to remedy this situation. This article argues for the application of the Drittwirkung concept to give a horizontal effect to a right against slavery. Furthermore it is argued that New Zealand is under positive obligations to actively prevent rights violations, not merely avoid them. These positive obligations are a key component of modern human rights jurisprudence and can be read into the New Zealand Bill of Rights Act 1990. This article speculates that one action courts could take is to undertake the development of a tort action against slavery.

\section{INTRODUCTION}

You may choose to look the other way but you can never again say that you did not know. - William Wilberforce $^{1}$

Slavery is often characterised by images of slaves traipsing their chained and bleeding feet onto America-bound ships, towards the marketplace for sale; towards plantations to be worked until death. ${ }^{2}$ Many see Wilberforce's abolition of slavery in the 1800 s as a triumph of humanity over barbarity. Yet slavery is not merely a historic atrocity. It is a present reality for over 35 million people worldwide. ${ }^{3}$ Once shipped across the Atlantic, slaves are now trafficked throughout the

* Article submitted as part of the LLB(Hons) programme at Victoria University of Wellington. I am grateful to Associate Professor Petra Butler for her invaluable guidance and supervision in writing this article.

1 Walk Free Foundation The Global Slavery Index 2014 (2014) at 4.

2 Anti-Slavery International "What is Modern Slavery?" <www.antislavery.org>.

3 Walk Free Foundation, above n 1, at 5. 
world. Once trapped by chains, they are now hidden in basements and overseas factories. Once openly justified through science and religion, slavery is now implicitly condoned by consumer choices and insatiable demand for cheaper products.

World Cups, Olympic and Commonwealth Games have provoked controversy over the working conditions of those constructing the tournament infrastructure. ${ }^{4}$ Pressure is currently on Qatar to improve the labour standards of hundreds of thousands of migrant workers in advance of the 2022 FIFA World Cup. ${ }^{5}$ The clothing industry is similarly concerning. In 2013 a Bangladeshi factory supplying Western brands collapsed, killing 1,100 workers who had been forced to enter the building despite safety concerns. ${ }^{6}$

Although New Zealand is far better than countries such as India, which has an estimated 14 million enslaved people, New Zealand is no safe haven. At the time of writing there were approximately 600 people trapped in slavery situations in New Zealand. ${ }^{7}$ This exceeds both the average annual road toll $(300),{ }^{8}$ and the homicide rate $(80) ;{ }^{9}$ issues which receive considerable media attention and government investment in preventative efforts. Yet slavery, occurring at a comparable frequency, is the subject of far less discussion and focused action. Specific problem areas are foreign vessels fishing in New Zealand waters, and the construction, agriculture, restaurant and prostitution industries. ${ }^{10}$ Many women willingly enter New Zealand to work in the sex industry and are subsequently forced into exploitative situations. ${ }^{11}$ Especially concerning is the internal trafficking of underage girls for commercial sexual exploitation. ${ }^{12}$ Christchurch's booming construction industry has fuelled exploitative migrant recruitment practices. ${ }^{13}$ Recruited workers

4 John Ray "China's disabled children are sold into slavery as beggars" (22 July 2007) The Guardian <www.theguardian.com>; "Delhi's Commonwealth Games slave labour shame" (2 February 2010) Herald Sun $\langle$ www.heraldsun.com.au>.

5 Dave Zirin "Slave Labour? Mass Prisons? FIFA Mangles the World Cup and the Beautiful Game" (26 September 2013) The Nation <www.thenation.com>.

6 Institute for Global Labour and Human Rights "Factory Collapse in Bangladesh" (24 April 2014) <www.globallabourrights.org>

7 Walk Free Foundation, above n 1, at 20-21.

8 New Zealand Transport Agency "Road death statistics" (10 June 2014) <www.nzta.govt.nz>.

9 Police National Headquarters NZ Crime Statistics: A Summary of Recorded and Resolved Offence Statistics (2014) at 2 .

10 Walk Free Foundation Global Slavery Index 2013 (2013) at 91; and United States Department of State Trafficking in Persons Report (2014) at 291.

11 United States Department of State Trafficking in Persons Report (2009) at 222.

12 United States Department of State, above n 10, at 291.

13 See Michael Morrah "Christchurch rebuild migrants face debts, cramped accommodation" (16 July 2014) 3 News <www.3news.co.nz>. 
have their original contracts replaced upon arrival, their identity documents confiscated, substantial debts incurred against them and are crammed into degrading living conditions. ${ }^{14}$

New Zealand's admirable human rights record does not afford room for complacency. This article argues that New Zealand needs to improve its current legal protections against slavery. It needs to ensure that the laws addressing slavery communicate clearly and prohibit explicitly the harm central to slavery, ownership of another human. This issue was addressed in respect of the United Kingdom in $C N v$ The United Kingdom $(C N v U K) .{ }^{15}$ This case affirmed the inadequacy of the United Kingdom's slavery legislation. More significantly however, the European Court of Human Rights (ECtHR) found that such an inadequacy constituted a breach of the United Kingdom's obligations under the Convention for the Protection of Human Rights and Fundamental Freedoms (ECHR). ${ }^{16}$ This article suggests that not only are New Zealand's legal measures against slavery inadequate, but furthermore that that inadequacy is a breach of New Zealand's international obligations to prevent slavery. It will explore how the New Zealand Bill of Rights Act 1990 (Bill of Rights) can be used to improve those protections and so satisfy New Zealand's obligations regarding slavery.

\section{A DEFINITION OF SLAVERY}

Slavery, servitude, and forced or compulsory labour are closely related offences that are often prohibited and prosecuted together. ${ }^{17}$ Slavery is "the status or condition of a person over whom any or all of the powers attaching to the right of ownership are exercised". ${ }^{18}$ The Australian High Court found that these powers include: making a person an object of purchase; using a person and his or her labour in a substantially unrestricted manner; an entitlement to the fruits of a person's labour without commensurate compensation; and controlling and restricting a person's movement. ${ }^{19}$ Servitude is "an obligation to provide one's services that is imposed by the use of coercion, and is to be linked with the concept of 'slavery'". ${ }^{20}$ Forced or compulsory labour is "all work or service which is exacted from any person under the menace of any penalty and for which the said person has not

14 Steph Lambert Protecting the Vulnerable (Justice Acts New Zealand, 2014) at 14.

15 CN v The United Kingdom (2013) 56 EHRR 24 (Section IV, ECHR).

16 Convention for the Protection of Human Rights and Fundamental Freedoms 213 UNTS 222 (opened for signature 4 November 1950, entered into force 3 September 1953) [ECHR].

17 International Covenant on Civil and Political Rights 999 UNTS 171 (signed 16 December 1966, entered into force 23 March 1976) [ICCPR], art 8; and ECHR, above n 16, art 4.

18 Slavery Convention 182 UNTS 51 (signed 25 September 1926, entered into force 9 March 1927), art 1 (emphasis added).

$19 R v$ Tang [2008] HCA 39, (2008) 237 CLR 1 at [26].

20 Siliadin v France (2006) 43 EHRR 16 (Section II, ECHR) at [124]. 
offered himself voluntarily". ${ }^{21}$ These three offences represent varying grades of severity but can occur simultaneously. ${ }^{22}$ Delineating the precise borders between these three offences is beyond the scope of this article. For ease of purpose, "slavery, servitude and forced or compulsory labour" will hereinafter be referred to as "slavery" unless otherwise indicated.

In recent years it has been suggested that human trafficking for exploitation is also a related concept. Trafficking consists of three elements: (a) an action facilitating migration; (b) committed by certain means; (c) for the purpose of exploitation. Trafficking's core concern with the movement of individuals renders it primarily an immigration issue. Whilst slavery can be a purpose of human trafficking, slavery and trafficking are not synonymous. ${ }^{23}$ It is unclear to what extent trafficking should fall within international slavery provisions. ${ }^{24}$ Failing to differentiate between them could result in slavery being overlooked, as occurred in $C N v U K .^{25}$ Trafficking must be treated as distinct.

States are rarely directly responsible for slavery - it is largely a private and secret enterprise which states struggle to identify, let alone prevent. There are numerous different forms of modern slavery involving relationships from the obviously exploitative to more subtle, complicated, fearbased dependencies. ${ }^{26}$ It is important to distinguish between slavery and poor employment situations. ${ }^{27}$ Late payment of wages, no holiday pay, non-guaranteed hours, and poor health and safety conditions are examples of substandard employment environments. ${ }^{28}$ However, the temptation to announce these sorts of employment law breaches as slavery must be avoided. The severity of true slavery situations, involving ownership of another human, must not be thus diminished.

21 Convention Concerning Forced or Compulsory Labour 39 UNTS 55 (signed 28 June 1930, entered into force 1 May 1932), art 2(1).

22 Vladislava Stoyanova "Dancing On the Borders of Article 4: Human Trafficking and the European Court of Human Rights in the Ranstev Case" (2012) 30 NQHR 163 at 181 and 182.

23 At $169-170$ and 177.

24 At 164

$25 C N v$ The United Kingdom, above n 15, at [80].

26 Manfred Nowak UN Covenant on Civil and Political Rights: CCPR Commentary (2nd ed, NP Engel, Germany, 2005) at 195-196; and Walk Free Foundation, above n 1, at 10-11.

27 International Labour Organization The cost of coercion: Global Report under the follow-up to the ILO Declaration on Fundamental Principles and Rights at Work (Report I(B), 98th Session, 2009) at [23].

28 Sylvia Yuan, Trudie Cain and Paul Spoonley Temporary migrants as Vulnerable Workers: A literature review (Ministry of Business, Innovation \& Employment, March 2014) at 9. 


\section{CN v THE UNITED KINGDOM}

This case demonstrates that, although abolished, slavery remains inadequately addressed, even in developed countries. Particularly, it illustrates how deficiencies in legislation can leave slavery victims without remedy. Furthermore it is an example of positive obligations being imposed on a state regarding slavery.

\section{A Facts}

The applicant was willingly smuggled into the United Kingdom in 2002. Upon her arrival her vulnerability, isolation and fear were exploited by her captors to create dependency. She was sent to an elderly Iraqi couple where she worked for four years as a live-in carer. The majority of the International Labour Organization's (ILO) forced labour indicators were present in her situation. The indicators are:

(a) abuse of vulnerability;

(b) deception;

(c) restriction of movement;

(d) isolation;

(e) physical and sexual violence;

(f) intimidation and threats;

(g) retention of identity documents;

(h) withholding of wages;

(i) debt bondage;

(j) abusive working and living conditions; and

(k) excessive overtime. ${ }^{29}$

The applicant was a victim of indicators (a), (c), (d), (f), (g), (h), (i) and (k). ${ }^{30}$ In August 2006 she managed to alert police. Throughout the investigation the authorities focused on trafficking offences. ${ }^{31}$ A police unit specialising in trafficking ran the investigation. English law at the time only prohibited domestic servitude where trafficking had occurred. ${ }^{32}$ That offence was consequently not applicable because she had immigrated willingly. Her solicitor requested investigation into other offences. However, the police concluded that there was no evidence of trafficking for exploitation even though slavery and forced labour were supposedly under investigation. They said there were

29 International Labour Office ILO indicators of Forced Labour (International Labour Organization: Special Action Programme to Combat Forced Labour, October 2012) at 3.

30 CN v The United Kingdom, above n 15, at [20].

31 At [76].

32 At [29]. See Asylum and Immigration (Treatment of Claimants, etc) Act 2004 (UK), s 4. 
no offences in English law that applied to her situation and she was left without a remedy. ${ }^{33}$ In January 2008 the applicant lodged an application against the United Kingdom with the ECtHR. ${ }^{34}$ In 2009 the United Kingdom made slavery, servitude, and forced or compulsory labour offences in accordance with the ECHR. ${ }^{35}$

\section{B Submissions}

The applicant claimed the United Kingdom was positively obligated to criminalise domestic servitude. It had breached that obligation by only criminalising conduct peripheral to domestic servitude. She argued that her treatment was consistent with that in Siliadin v France (Siliadin). ${ }^{36}$ Consequently the positive obligation to criminalise the specific conduct of the ECHR should be affirmed. ${ }^{37}$ She alleged that the police were ignorant of relevant factors regarding domestic servitude. Furthermore the lack of domestic law provisions at the time prevented effective investigation and prosecution of the perpetrators. ${ }^{38}$ The United Kingdom argued firstly that the investigation was not terminated because of an absence of applicable criminal offences. Rather there was insufficient evidence that she was a victim of domestic servitude. ${ }^{39}$ Secondly, it argued that criminalising aspects of slavery in various independent sections adequately satisfied the positive obligations. ${ }^{40}$

\section{Decision}

The ECtHR came to three key conclusions. Firstly, the applicant's situation aroused credible suspicion that she had been a victim of domestic servitude. Article 4 of the ECHR imposes specific positive obligations on member states to penalise and prosecute slavery. These involve operational measures to protect victims and procedural obligations to investigate suspected violations when the member state is aware of the risk of violation. ${ }^{41}$ The Government's credible suspicion of the violation against the applicant thus obligated it to investigate. ${ }^{42}$ Secondly, the United Kingdom's legislation provided insufficient protection against the art 4 conduct. As in Siliadin, the relevant

33 CN v The United Kingdom, above n 15, at [16] and [29].

34 At [1].

35 At [31]; and Coroners and Justice Act 2009 (UK), s 71.

36 Siliadin v France, above n 20.

37 CNv The United Kingdom, above n 15, at [42], [48] and [51].

38 At [49]-[50].

39 At [54].

40 At [56].

41 At [66], [67] and [69].

42 At [70]-[72]. 
legislation was "not sufficiently specific" and "too restrictive". The Court pointed to the increasingly high standard of rights protection expected internationally. Accordingly there is a need to specifically criminalise domestic servitude, not just associated behaviours. ${ }^{43}$ Thirdly, the Court confirmed that the failure to pay attention to the complex factors of domestic servitude was due to the legislation's trafficking focus. The provision of an inadequate investigation violated art $4 .{ }^{44}$

\section{NEW ZEALAND'S LEGAL SITUATION}

Akin to the former United Kingdom position, New Zealand's legal framework and remedies provide insufficient protection against slavery. First, note that there are several common misconceptions surrounding protections against slavery which do not in fact provide such protection. Contrary to popular belief, habeas corpus does not provide protection against slavery in New Zealand despite the decision in Somerset $v$ Stewart. Somerset $v$ Stewart did not free all slaves; it stood only for the rule that no slave could be forcibly removed from England. ${ }^{45}$ In addition, while the International Crimes and International Criminal Court Act 2000 prohibits "enslavement", it does not apply to isolated incidents of slavery so does not address the conduct at issue in this article. ${ }^{46}$

\section{A Criminal Law}

Criminalisation is required to address slavery. Unfortunately, most slavery legislation worldwide is poorly enforced and New Zealand is no exception. ${ }^{47}$ In New Zealand, slavery and forced labour are criminalised in ss 98 and 98AA of the Crimes Act 1961 with maximum sentences of 14 years. These provisions are independent of the trafficking offences.

Section 98(2) defines a slave as including, "without limitation, a person subject to debt-bondage or serfdom". Serfdom is further defined as:

the status or condition of a tenant who is by any law, custom, or agreement bound to live and labour on land belonging to another person and to render some determinate service to that other person, whether for reward or not, and who is not free to change that status or condition.

43 At [75]-[76]. See Siliadin v France, above n 20, at [142]. See generally Recommendation 1523 (2001) of the Parliamentary Assembly of the Council of Europe at [9].

44 CNv The United Kingdom, above n 15, at [80]-[82].

45 Somerset v Stewart (1722) 98 ER 499. See Paul D Halliday Habeas Corpus: From England to Empire (Harvard University Press, Cambridge (Mass), 2010) at 175.

46 Rome Statute of the International Criminal Court 2187 UNTS 90 (opened for signature 17 July 1998 , entered into force 1 July 2002), art 7(1) and (2), sch to the International Crimes and International Criminal Court Act 2000.

47 Walk Free Foundation, above n 10, at 10. 
Debt-Bondage is defined as: ${ }^{48}$

the status or condition arising from a pledge by a debtor of his or her personal services, or of the personal services of any person under his or her control, as security for a debt, if the value of those services, as reasonably assessed, is not applied towards the liquidation of the debt or if the length and nature of those services are not limited and defined.

While this definition of slavery is framed to allow flexibility, it does not encapsulate the "right of ownership" central to international definitions of slavery. ${ }^{49}$ It also has been framed to include servitude. The definition of serfdom in s 98(2) bears close resemblance to the ECtHR's definition of servitude. ${ }^{50}$ As discussed above, slavery and servitude are related but correspond to different levels of severity. ${ }^{51}$ Their amalgamation thus reveals a limited understanding of the nature and circumstances giving rise to each of them. If courts read this provision down towards servitude it could diminish the perceived gravity of the offence. Alternatively, if courts read this provision up towards slavery, servitude-type situations that do not meet the threshold for slavery may slip through the cracks. Both situations impair the effectiveness of any protection offered.

Section 98AA prohibits sexual exploitation, removal of body parts and forced labour. Whilst sexual exploitation is defined extensively, forced labour is not at all. ${ }^{52}$ This is partly explained by s 98AA having been introduced to comply with a children's rights convention. ${ }^{53}$ The inclusion of forced labour was merely incidental to the primary concern - protecting children from sexual exploitation. The protection offered against forced labour is thus less comprehensive than it ought to be.

Action against slavery is currently inhibited by the lack of prosecutions. This is due in part to a lack of understanding of the nature of enslavement itself attributable to the deficient definitions described above. ${ }^{54}$ For example, in 2001, 15 smuggled Thai women were forced into prostitution and their earnings were confiscated to repay imposed debts. The culprits were never convicted because the police believed the absence of physical restraints meant the case would likely fail. Yet a

48 Crimes Act 1961, s 98(2)

49 Slavery Convention, above n 18, art 1; and Siliadin v France, above n 20, at [122].

50 See Siliadin v France, above n 20, at [123]; and Crimes Act 1961, s 98(2).

51 International Labour Organization, above n 27, at [43].

52 Crimes Act 1961, s 98AA(3)-(6).

53 (2 March 2004) 615 NZPD 11472; and Optional Protocol to the Convention on the Rights of the Child on the Sale of Children, Child Prostitution and Child Pornography 2171 UNTS 227 (opened for signature 25 May 2000, entered into force 18 January 2002).

54 United States Department of State, above n 10, at 292. 
number of the forced labour indicators were present. ${ }^{55}$ There is some evidence that courts have been choosing to prosecute under employment or immigration provisions rather than under ss 98 and $98 \mathrm{AA} .{ }^{56}$ To improve the investigative processes and secure more convictions for slavery offences, greater knowledge of slavery is necessary. A clearer definition of slavery and greater judicial awareness of the aforementioned indicators would help courts to know when and how to apply ss 98 and 98AA.

One successful prosecution under s 98 involved a man being convicted of selling a woman as a slave ${ }^{57} \mathrm{He}$ had assisted her entry into the country and lived off her earnings before offering to sell her to an undercover police officer. He was found guilty under s 98(1)(a) and (j) and sentenced to five years imprisonment followed by deportation. ${ }^{58}$ The Court of Appeal said accepted the trial Judge's definition that slavery is submission to domination where domination means "control and authority that brooks no opposition or disobedience".59 There was no reference to ownership. However, in awarding the sentence, the trial Judge had equated the accused's behaviour with rape and had emphasised the need to deter others from acting similarly. ${ }^{60}$ This was recognition of the seriousness of slavery which should be emulated in other cases. The approach could have been further improved through reference to the concept of ownership.

\section{B Tort Law}

There are a number of civil actions that could provide some protection to victims of slavery. These include the torts of assault, battery, false imprisonment, deceit and mental injury. Assault's requirement that there be an intentional act causing apprehension of physical contact, and battery's requirement of an intentional act of contact with the plaintiff's body, will often be satisfied in slavery incidents. False imprisonment requires the "total deprivation of liberty" of the plaintiff. This can include psychological imprisonment achieved through threats or assertions of authority. ${ }^{61}$ The

55 Susan Glazebrook, Justice of the New Zealand Court of Appeal "Human Trafficking and New Zealand" (keynote address to AGM of the New Zealand Women Judges Association, Auckland, 13 August 2010) at 9; and International Labour Office, above n 29, at 3.

56 Thomas Harré "Human trafficking in New Zealand: a review of recent case law" NZ Lawyer (New Zealand, 17 January 2014). See generally Elliott (Labour Inspector) v Kirk ET Auckland AET581/00, 19 February 2001; and $R v$ Rahimi CA4/02, 30 April 2002.

$57 \quad R$ v Decha-Iamsakun [1993] 1 NZLR 141 (CA).

58 At 142 .

59 At 144

60 At 148

61 Pam Stewart "Tortious Remedies for Deliberate Wrongdoing to Victims of Human Trafficking and Slavery in Australia" (2011) 34 UNSWLJ 898 at 908-911; and Stephen Todd (ed) The Law of Torts in New Zealand (6th ed, Brookers, Wellington, 2013) at [4.5.01]. 
tort of deceit is primarily applicable in commercial situations so would need some extension before it could be properly useful in slavery situations. Action for mental injury is generally available in New Zealand. ${ }^{62}$ However, work-related mental injury and mental injury caused by sexual offences are covered by the Accident Compensation Act $2001 .{ }^{63}$ To the extent that slavery situations are considered "employment", a tort action for mental injury is thus unavailable.

Whilst these torts may be applicable in some slavery situations there are several issues. First, not all slavery situations will be covered by all of these torts. This could lead to inconsistent treatment of slavery in the courts and victims receiving different remedies. Secondly, whilst these torts indeed provide some remedy for victims, they do not address the issue at the heart of slavery. There is a difference between an assault in a bar fight and being threatened during enslavement. Slavery is one of the most serious violations of human rights, involving ownership of another human being. The severity of this sort of behaviour should not be diminished by association with lesser wrongdoing. Consequently, the current tort actions do not provide sufficient protection against slavery.

\section{Other Measures}

It should be noted that although New Zealand has extensive employment regulations there are nonetheless some types of workers unprotected by that regime. These can include contractors, triangle employment arrangements, illegal workers and migrant workers. ${ }^{64}$ The Government has taken steps towards monitoring high risk industries. ${ }^{65}$ However, New Zealand does not have a law enforcement unit specifically trained to identify, prevent, monitor and address modern slavery situations. ${ }^{66}$ There needs to be further investigation into how the basic employment rights given to employees can be extended to all workers. ${ }^{67}$

\section{In Summary}

The lack of clear, delineated and internationally consistent definitions of slavery in New Zealand's legislation inhibits effective prosecution of slavery. So too does the absence of a specific tort action concerning enslavement. Whether New Zealand is obligated to remedy this will be discussed below.

62 Todd, above n 61, at [5.7].

63 Accident Compensation Act 2001, ss 21 and 21B.

64 Lambert, above n 14, at 24.

65 United States Department of State, above n 10, at 292.

66 Walk Free Foundation, above n 10, at 92.

67 See Lambert, above n 14, at 24 and 32 for more information. 


\section{A BILL OF RIGHTS INTERPRETATION}

This article now considers whether the Bill of Rights can be used to interpret the Crimes Act sections in a way that extends the protection provided.

\section{A Slavery and the Bill of Rights}

Slavery is not referred to in the Bill of Rights. Given that slavery is primarily committed by private individuals, it can be classified as a horizontal right. ${ }^{68}$ However, the Bill of Rights supposedly applies to vertical rights where there is state action satisfying s $3 .{ }^{69}$ Furthermore, the Bill of Rights focuses more on procedural rights than substantive rights. ${ }^{70}$ However, with the doctrine of positive obligations, discussed below, the exclusion of slavery on that basis should be considered flawed - judicial action in private slavery cases would have to comply.

Constitutional provisions often provoke the development of other laws, serve an educative function and filter new law. This on its own does not satisfy positive obligations. Despite the United Kingdom's constitutional protections against slavery, it still breached its positive obligations in $C N v$ $U K{ }^{71}$ The ECtHR focused more on practical operational measures to protect victims. ${ }^{72}$ The absence of a constitutional provision weakens the protections offered against slavery, however that absence does not necessarily correlate with a breach of New Zealand's positive obligations.

The absence of slavery in the Bill of Rights could be ameliorated by reading it in. This does not give slavery the prominence and protection it would have received through express inclusion in the Bill of Rights but it is an improvement on the present situation. The Bill of Rights must be read generously and in light of the International Covenant on Civil and Political Rights (ICCPR). ${ }^{73}$ Some academics consider that the ICCPR cannot be used to fill gaps in the Bill of Rights deliberately left by Parliament. ${ }^{74}$ However, the treatment of privacy indicates that where the ICCPR has not been transposed, missing rights may be read in to provide at least some protection. ${ }^{75}$ In both Hosking $v$ Runting (Hosking) and $C v$ Holland, the Court read privacy into the right against unreasonable

68 See Part II: A Definition of Slavery, above; and Nowak, above n 26, at 39 and 195.

69 Geoffrey Palmer "A Bill of Rights for New Zealand: A White Paper" [1984-1985] I AJHR A6 at [10.12] and [10.16].

70 (10 October 1989) 5502 NZPD 13040.

71 Human Rights Act 1998 (UK), sch 1.

72 CN v The United Kingdom, above n 15, at [67].

73 ICCPR, above n 17. See Andrew Butler and Petra Butler The New Zealand Bill of Rights: a commentary (LexisNexis, New Zealand, 2005) at [4.2.3]-[4.2.5].

74 At [4.5.11].

75 New Zealand Bill of Rights Act 1990, s 28. 
search and seizure. ${ }^{76}$ Privacy was an existing legal value and its absence from the Bill of Rights did not constitute its "legislative rejection". ${ }^{77}$ However, it was found that unless Parliament explicitly restricts development in a particular area, courts can consider themselves free to develop the common law. ${ }^{78}$ Courts may even be obligated to do so where international values have been ratified by New Zealand. ${ }^{79}$

The right into which slavery can best be read is most likely the right not to be subjected to torture or cruel, degrading or disproportionately severe treatment. ${ }^{80}$ In Ranstev $v$ Cyprus and Russia, the ECtHR addressed the torture and slavery allegations together because of their similarities. ${ }^{81}$ Furthermore, the word treatment has been read as applying to all behaviour inconsistent with human dignity and value, not just criminal justice and disciplinary processes. ${ }^{82}$ Slavery is certainly inconsistent with human dignity and value. Other rights such as freedom of movement, the right to liberty and the right to justice are too narrow themselves to allow slavery to be read in. ${ }^{83}$ However, under a schematic approach to the Bill of Rights these rights support the argument for reading slavery into torture. ${ }^{84}$

\section{B Section 6 Analysis}

Section 6 requires the preference of a Bill of Rights-consistent meaning of an enactment. Parliament should specify if it does not intend to affirm the Bill of Rights. ${ }^{85}$ However, courts "cannot rewrite or legislate". ${ }^{86}$ The phrase "includes, without limitation" means slavery could be read widely to include behaviour other than debt bondage or serfdom. This would certainly be more consistent with the Bill of Rights than restricting the scope to only those two behaviours. However, the goal of applying s 6 to s 98 of the Crimes Act is to read the definition of slave widely enough to

76 Hosking v Runting [2005] 1 NZLR 1 (CA) at [60]; C v Holland [2012] NZHC 2155, [2012] 3 NZLR 672 at [25].

77 Hosking $v$ Runting, above n 76, at [92]; and $C$ v Holland, above n 76, at [28]-[31].

78 Hosking $v$ Runting, above $\mathrm{n} 76$, at [228] per Tipping J; and $C v$ Holland, above $\mathrm{n} 76$, at [81].

79 C v Holland, above n 76, at [69].

80 New Zealand Bill of Rights Act 1990, s 9.

81 Ranstev v Cyprus and Russia (2010) 51 EHRR 1 (Section I, ECHR) at [252].

82 Butler and Butler, above n 73, at [10.1.4], [10.3.1] and [10.9.1].

83 New Zealand Bill of Rights Act 1990, ss 18, 22 and 27.

84 See the discussion in Part $V I(B)(2)(d)$ of this article about the values approach used in Germany and India for insight into this approach.

85 Ministry of Transport v Noort [1992] 3 NZLR 260 (CA) at 287 per Hardie Boys J.

86 Quilter v Attorney-General [1998] 1 NZLR 523 (CA) at 572 per Tipping J. 
incorporate the idea of ownership inherent in other definitions of slavery. Exercising ownership over another human being is a severe action. Reading that concept into s 98 is not something the courts should do absent a legislative mandate. Furthermore, a whole separate offence of servitude could not be added in merely through a s 6 analysis.

Regarding s 98AA, a meaning of forced labour consistent with the Bill of Rights could be found by using the definition contained in Part II of this article. However, the other two behaviours in $\mathrm{s}$ 98AA are sexual exploitation and removal of body parts. To read forced labour as referring to "all work or service" extracted involuntarily and under threats is to introduce a very different and quite substantial concept into the section. It does not fit well.

Reading ss 98 and 98AA consistently with the Bill of Rights certainly improves the situation. However, it still does not provide the comprehensive protection against slavery that is necessary. This can be illustrated by a comparison with the Australian legislation. The Australian Criminal Code Act 1995 (Cth) slavery provisions are internationally regarded as well-crafted with clear definitions and distinctions between behaviours. ${ }^{87}$ Slavery, servitude, and forced or compulsory labour are separately defined and prohibited using wording consistent with international definitions. ${ }^{88}$ Even a wide interpretation of the Crimes Act could not achieve the precise and comprehensive protection offered by the Australian Act.

\section{ALTERNATIVE APPROACHES}

To the extent that the Bill of Rights is unable to remedy the defects in the Crimes Act, there are two alternative ways the Bill of Rights can provide protection against slavery. First, Drittwirkung is a concept by which human rights can be invoked in the private sphere because they have a horizontal effect as well as a vertical one. It refers to the effect of human rights between private parties. ${ }^{89}$ Courts must interpret and apply the law between private parties consistently with human rights. ${ }^{90}$ Secondly, this article will explore the obligations on states to take measures to protect human rights against private violation. New Zealand is under positive obligations to protect against slavery. This means that New Zealand must actively prevent slavery occurring within its jurisdiction even when committed by private individuals.

87 Vladislava Stoyonava "Article 4 of the ECHR and the Obligation of Criminalising Slavery, Servitude, Forced Labour and Human Trafficking" (2014) 3 CJICL 407 at 441.

88 Criminal Code Act 1995 (Cth), ss 270-271.

89 BVerfGE, 7, 198 I. Senate (1 BvR 400/51) [Lüth]; and Nowak, above n 26, at 39.

90 Chava Schwebel "Welfare Rights in Canadian and German Constitutional Law" (2011) 12 GLJ 1902 at 1926; and Lüth, above n 89. 


\section{A Drittwirkung}

Protecting against slavery, a predominantly horizontal right, requires more than mere state nonaction. ${ }^{91}$ Modern slavery is undertaken primarily by private parties, so for protection to be effective it must be broad enough to cover those private parties. However, citizens cannot ordinarily invoke the Bill of Rights against one another. ${ }^{92}$ Nonetheless, the Bill of Rights can apply in the private sphere through the application of the Drittwirkung concept. Its implication is that courts, when they apply both legislation and the common law, can extend those private relationships in order to protect the rights contained in the Bill of Rights.

The key objection to this is that s 3 of the Bill of Rights limits its application to state and public functions. It is argued that the Bill of Rights cannot reach into areas of life where personal autonomy is unaffected by the state. ${ }^{93}$ However, most private conduct is regulated by law and to that extent is public. ${ }^{94}$ Therefore the public bodies that create and monitor those private laws must, as they do so, apply the Bill of Rights. ${ }^{95}$ This requires more than the mere compliance of procedural rules; the substantive outcomes of those processes must involve an application of the Bill of Rights also. Rights thus do affect the "structuring of relationships under private law". ${ }^{96}$ A private individual claiming under existing legislation or common law is able to "demand a Bill of Rights consistent judicial determination". 97

The real controversy arises when giving effect to the Bill of Rights would require the courts to significantly alter existing causes of action or to create new ones entirely. ${ }^{98}$ For instance, a slavery victim might sue for assault but fail to prove the requisite elements. Despite this, the courts, recalling that slavery can be read into the Bill of Rights, might determine that to protect the victim adequately and give effect to the Bill of Rights in this context, the development of a tort of slavery is necessary. Similarly, where statutes contain ambiguous terms, Drittwirkung works to allow courts

91 Nowak, above n 26, at 196.

92 New Zealand Bill of Rights Act 1990, s 3.

93 Murray Hunt "Human Rights Review and the Public-Private Distinction" in Grant Huscroft and Paul Rishworth (eds) Litigating Rights: Perspectives from Domestic and International Law (Hart Publishing, Portland, 2002) 3 at 77.

94 Andrew Clapham (ed) Human Rights in the Private Sphere (Oxford University Press, Oxford, 1993) at 94 and 131-132.

95 Jan Stemplewitz "Horizontal rights and freedoms: an analysis of the role and effect of the New Zealand Bill of Rights Act 1990 in private litigation" (LLM Research Paper, Victoria University of Wellington, 2005) at 6 and 9.

96 Nowak, above n 26, at 39.

97 Stemplewitz, above n 95, at 14.

98 At 17 and 25. 
to expand rights protections. ${ }^{99}$ Given the above s 6 analysis of the Crimes Act, the common law application of Drittwirkung is more useful with regard to slavery.

Some support for this private sphere application of human rights can be found in the New Zealand case law. ${ }^{100}$ Unlike Blanchard J, who was reluctant to apply the Bill of Rights to the substance of the judiciary's judgments, ${ }^{101}$ later cases have not been so conservative. ${ }^{102}$ In Lange $v$ Atkinson, Elias J distinguished the Canadian approach because the Canadian Charter does not refer to judicial acts as does New Zealand's Bill of Rights. She said that "[i]t is idle to suggest that the common law need not conform to the judgments in such legislation." 103 The Canadian approach was enunciated in a libel case between private parties. The Court said that without state attributable acts Charter rights are not actionable. ${ }^{104}$ In private cases the common law must be applied consistently with the Charter, however it cannot be revised and supplemented in the way discussed above merely to give effect to the Charter. ${ }^{105}$ Paul Rishworth would have New Zealand adhere to the Canadian approach, characterising the Bill of Rights merely as a limitation on state action. ${ }^{106}$

Nonetheless, in both Solicitor-General v Radio New Zealand and Duff v Communicado (Duff) the Bill of Rights was applied "to acts done by the judicial branch of the Government". ${ }^{107}$ In fact, the High Court in Duff explicitly indicated that this finding applied generally to the common law. ${ }^{108}$ Tipping $\mathbf{J}$ in Hosking said that whilst the Bill of Rights regulates the relationship between the state and its citizens:109

[I]t will often be appropriate for the values which are recognised in that context to inform the development of the common law in its function of regulating relationships between citizen and citizen.

99 Simpson v Attorney-General [1994] 3 NZLR 667 (CA) [Baigent's Case] at 676; and see Butler and Butler, above $\mathrm{n}$ 73, at [5.6.6]-[5.6.8].

100 Butler and Butler, above n 73, at [5.8.10].

101 Television New Zealand Ltd v Newsmonitor Services Ltd [1994] 2 NZLR 91 (HC) at 96.

102 Hunt, above n 93, at 75 .

103 Lange v Atkinson [1997] 2 NZLR 22 (HC) at 32.

104 Hill v Church of Scientology of Toronto [1995] 2 SCR 1130 at [82].

105 At [95]. See also Dolphin Delivery Ltd v Retail, Wholesale and Department Store Union, Local 580 [1986] 2 SCR 573.

106 Paul Rishworth and others The New Zealand Bill of Rights (Oxford University Press, Oxford, 2003) at 102108; and Hunt, above n 93, at 77.

107 Solicitor-General v Radio NZ Ltd [1994] 1 NZLR 48 (HC) at 58.

108 Duff v Communicado Ltd [1996] 2 NZLR 89 (HC) at 99.

109 Hosking $v$ Runting, above n 76, at [229] per Tipping J. 
Consequently when courts apply substantive law to private situations they must give effect to the Bill of Rights. Thus, when slavery arises before the courts, the courts would be obligated to use the Bill of Rights to remedy the current deficient protections and address the behaviours at the core of slavery.

\section{B Positive Obligations}

Arguably the common law cannot be fully subject to the Bill of Rights unless there are positive obligations upon the state. The ultimate effect of these would be that New Zealand is obligated to remedy the current slavery protections even though it concerns acts between private parties. ${ }^{110}$ This could be done in a variety of ways from the courts developing new causes of action to Parliament amending old or introducing new legislation.

\section{Doctrine of positive obligations}

Historically human rights were concerned with preventing state action, not requiring it. ${ }^{111}$ Recently the language of human rights instruments has suggested something more: positive obligations. States are obligated to exercise due diligence to prevent and remedy human rights violations. Failure to do so results in state liability even when the actual violation was committed by a non-state actor. ${ }^{12}$ States are not responsible for every human rights abuse incident. ${ }^{113}$ The distinct injuries occurring must be fairly attributed between the non-state actor and the state. For instance, an act of torture produces individual culpability, but the failure to sufficiently deter or subsequently prosecute produces state culpability. The responsibility under due diligence is to avoid the stateattributable harm. This approach is advocated by the non-repression theory which has been favoured by some over the "'presumed complicity' theory of state responsibility". The latter requires states to have some knowledge or a credible suspicion of the threat of a right being violated. ${ }^{114}$ For slavery this is impractical because, as demonstrated in $C N v U K$, slavery is often too well hidden for threats to come easily to the attention of the government.

Positive obligations are a combination of express textual requirements and "implied judicial creations". ${ }^{115}$ A number of articles in the ICCPR and the ECHR, such as slavery and propaganda for

110 Stemplewitz, above n 95, at 17 and 25-26; and Clapham, above n 94, at 342.

111 H Lauterpacht International Law and Human Rights (2nd ed, Stevens \& Sons, London, 1950) at 155.

112 Danwood Mzikenge Chirwa "State Responsibility for Human Rights" in Mashood A Baderin and Manisuli Ssenyonjo (eds) International Human Rights Law: Six Decades after the UDHR and Beyond (Ashgate, Farnham, 2010) 397 at 404-407. See generally Corfu Channel (United Kingdom v Albania) (Merits) [1949] ICJ Rep 4.

113 Clapham, above n 94, at 215.

114 Robert P Barnidge "The Due Diligence Principle Under International Law" (2006) 8 Int CL Rev 81 at 94.

115 Alastair Mowbray The Development of Positive Obligations under the European Convention on Human Rights by the European Court of Human Rights (Hart Publishing, Portland, 2004) at 2 and 44. 
war, contain express positive obligations. ${ }^{116}$ The application of these is not controversial, but their scope is the subject of much jurisprudence. ${ }^{117}$ States are given a wide margin of appreciation with criminal provisions only being required in the most severe circumstances. ${ }^{118}$

The ECtHR has also implied positive obligations into other articles. Respecting rights means avoiding violating them. However, the general requirement to protect, ensure and fulfil rights gives rise to the further obligation of guaranteeing them for others. ${ }^{119}$ The Court often combines a general provision with a substantive provision to create a positive obligation. ${ }^{120}$ It uses the principle of effectiveness to give provisions "the fullest weight and effect consistent with the language used and with the rest of the text" and to determine the scope of obligations. ${ }^{121}$ The Court's goal in interpreting the ECHR should be promoting human rights not limiting state responsibility. ${ }^{122}$ The Court has consequently implied positive obligations in otherwise negatively framed rights.

It is into the determination of scope of obligations that the margin of appreciation becomes important. ${ }^{123}$ Positive obligations have made even further inroads into state sovereignty than human rights in general. ${ }^{124}$ Governments may be compelled by an external party to take domestic actions. The ECtHR wishes to protect the sovereignty of states by not legislating for them, especially regarding more controversial issues. ${ }^{125}$ Consequently, states may often choose which measures they will undertake to meet their positive obligations. ${ }^{126}$ Defective legal regimes, lack of procedural safeguards and issues regarding important aspects of individual existence tend to result in narrower margins. Political controversy and lack of international consensus result in wider margins. For

116 ICCPR, above n 17, arts 6(1), 8, 10, 17(2), 20, 23(1), 24(1) and 26; and ECHR, above n 16, art 2.

117 Office of the United Nations High Commissioner for Human Rights State Responsibility to Regulate and Adjudicate Corporate Activities under the United Nations' core Human Rights Treaties (2007) at [18].

118 At [48]. See MC v Bulgaria (2005) 40 EHRR 20 (Section I, ECHR) at [150] and [152] per Tulkens J; and $X$ and $Y v$ The Netherlands (1985) 8 EHRR 235 (ECHR) at [24] and [27].

119 Office of the United Nations High Commissioner for Human Rights, above n 117, at 4.

120 Mowbray, above n 115, at 44.

121 JG Merrills The Development of International Law By The International Court of Human Rights (Manchester University Press, Manchester, 1988) at 89 and 94.

122 Clapham, above n 94, at 189.

123 Marckx v Belgium (1979) 2 EHRR 330 (ECHR) at [3] per Matscher J.

124 Christine Chinkin Third Parties in International Law (Clarendon Press, Oxford, 1993) at 3.

125 Clapham, above n 94, at 344.

126 Daniel Augenstein State Responsibilities to Regulate and Adjudicate Corporate Activities Under the European Convention on Human Rights (Submission to the Special Representative of the United Nations Secretary-General (SRSG) on the issue of Human Rights and Transnational Corporations and Other Business Entities, 2011) at [23]. 
instance, there tends to be less uniformity across regarding economic, social and environmental issues. ${ }^{127}$

\section{New Zealand's positive obligations}

This section explores the reasoning behind imposing positive obligations on New Zealand. This is done through looking at domestic cases, Human Rights Committee (HRC) and ECtHR jurisprudence, the jurisprudence of other states and policy reasons. The consequence of these obligations is that New Zealand is obligated to provide better protection against slavery than currently exists.

(a) New Zealand cases

Few New Zealand courts have engaged in discussions about positive obligations and certainly none in regard to slavery. Where the issue of positive obligations has arisen, courts have tended to focus very narrowly on the facts, refusing to make a general statement of the law. The following five cases indicate the general approach taken towards positive obligations.

Sharma v ANZ Banking Group concerned freedom from unreasonable search and seizure. Bailiffs had failed to discriminate between the appellant's property and his wife's property. ${ }^{128}$ Whilst his claims regarding the bailiffs' behaviour failed, it was suggested that, had he and his wife combined their claim, a new cause of action may have arisen from the Bill of Rights despite being a private situation. ${ }^{129}$ In Mendelssohn v Attorney-General, the Court of Appeal said that in that case freedom of religion was a negative freedom so no positive action was expected of the state to protect it. ${ }^{130}$ However, the Court also said that some parts of the Bill of Rights do expressly impose positive obligations. Additionally, in some circumstances, positive obligations may arise out of negative rights. ${ }^{131}$

In Shortland v Northland Health Ltd, the Court of Appeal said the right to life did not obligate the state to provide expensive medical treatment to a man with kidney failure. ${ }^{132}$ Whilst New Zealand courts have not yet explored the full extent of the state's obligation to protect life, this case

127 Jana Gajdošová "Article 8 ECHR and Its Impact on English Law" (PhD Thesis, University of East Anglia Law School, 2008) at $157-158$ and 202.

128 Sharma v ANZ Banking Group (1992) 6 PRNZ 386 (CA) at 3-4.

129 At 8 .

130 Mendelssohn v Attorney-General [1999] 2 NZLR 268 (CA) at [6] and [14].

131 At [15] and [20].

132 Shortland $v$ Northland Health Ltd [1998] 1 NZLR 433 (CA) at 445; and David Hart "The Impact of Human Rights on Medical Law" (paper published for One Crown Office Row, United Kingdom, October 2002). 
indicates that the scope of obligations will be limited in some circumstances. ${ }^{133}$ Clark v GovernorGeneral concerned positive obligations regarding torture. ${ }^{134}$ The plaintiff argued ss 9 and 23(5) of the Bill of Rights had been breached by the Government's failure to provide education, investigate allegations, review processes and protect against torture. ${ }^{135}$ The Government contended that no such obligations were expressly or impliedly included in those sections. ${ }^{136}$ The Judge held that the incorporation of those obligations depended on their justiciability. ${ }^{137}$ Education and reviews were non-justiciable because they were too political an issue. Impartial investigation and protection of claimants were justiciable because they are essential to the right against torture. ${ }^{138}$ However, on these facts the latter actions had been carried out by the Government so a final decision on incorporation of positive obligations was unnecessary. ${ }^{139}$

One Bill of Rights draft authorised courts to grant remedies in situations where no adequate remedy presently existed. ${ }^{140}$ Despite this being absent from the final version, courts have nonetheless developed remedies. In Simpson v Attorney-General, McKay J questioned how "rights can be protected and promoted if they are merely affirmed, but there is no remedy for their breach, and no other legal consequence". ${ }^{141}$ Courts' willingness to develop remedies in this way indicates their desire to protect and promote rights. Some gaps in the Bill of Rights have been interpreted as Parliament delegating authority to the judiciary to explore those areas themselves. ${ }^{142}$

In summary, the judiciary has indicated a willingness to develop the common law beyond what is specifically articulated in the Bill of Rights even in regard to rights that are framed negatively. ${ }^{143}$ This is dependent on the justiciability of the specific obligation and its extent is subject to some

133 Ministry of Justice "Guidelines on the New Zealand Bill of Rights Act 1990" (November 2004) <www.justice.govt.nz>.

134 Clark v Governor-General (2005) HC Wellington CIV-2004-485-1902, 27 May 2005 at [30] per Associate Judge Gendall.

135 At [13].

136 At [15].

137 At [57].

138 At [61]-[63].

139 At [76].

140 Palmer, above n 69, at [6.25].

141 Baigent's Case, above n 99, at 717.

142 At 718 per McKay J; $R$ v Butcher [1992] 2 NZLR 257 (CA) at 269 per Gault J; and $R v$ Shaheed [2002] 2 NZLR 377 (CA) at 410 per Blanchard J.

143 Butler and Butler, above n 73, at [26.8.1]. 
limitations. Courts are concerned with protecting rights and will act accordingly. The imposition of positive obligations is therefore an option well open to the courts.

\section{(b) Human Rights Committee}

The HRC has indicated that positive obligations are required for thorough protection of all rights - especially horizontal rights such as slavery. The ICCPR's general provision requires states to adopt legislation and all other necessary measures to give effect to rights. Failure to protect against rights abuse by private actors or to provide effective remedies violates the ICCPR. The duty to protect is not limited to the expressly positive articles. ${ }^{144}$ Positively framed rights merely generate stricter and narrower obligations than those that are negatively framed. ${ }^{145}$ For example, states must protect against torture committed by private actors despite being a negatively framed right. ${ }^{146}$ The ICCPR slavery provisions are framed positively and are read by the $\mathrm{HRC}$ as requiring prohibition by law. ${ }^{147}$

As with the ECHR, states are allocated a large discretion as to the measures required to meet those obligations. ${ }^{148}$ Article 2 suggests generally "judicial, administrative, educative or other appropriate measures". Some rights are more specific - requiring prohibition by law. ${ }^{149}$ The nature of a right is the biggest determining factor in what protection measures are required. ${ }^{150}$ For instance, the ICCPR does not provide a right to criminal prosecution of perpetrators. Nonetheless, criminalisation is urged in cases of serious violations. ${ }^{151}$

New Zealand courts have discussed the comments made by the HRC in William Eduardo Delgado Paez v Colombia. ${ }^{152}$ Colombia argued that it was only obligated to protect the security of a person arrested by the state. The HRC disagreed, interpreting the state's obligations widely. Even when the state merely knew of a threat they were required to act. ${ }^{153}$ This illustrates the HRC's

144 Office of the United Nations High Commissioner for Human Rights, above n 117, at [18]; and Human Rights Committee General Comment 31: Nature of the General Legal Obligation on States Parties to the Covenant CCPR/C/21/Rev.1/Add.13 (2004) at [6]-[8].

145 Office of the United Nations High Commissioner for Human Rights, above n 117, at [48].

146 Human Rights Committee General Comment 20: Article 7 HRI/GEN/1/Rev.1 (1994) at [2].

147 ICCPR, above n 17, art 8; and Office of the United Nations High Commissioner for Human Rights, above $\mathrm{n}$ 117 , at [12].

148 Office of the United Nations High Commissioner for Human Rights, above n 117, at [48].

149 At [10]; ICCPR, above n 17, art 2; and Human Rights Committee, above n 144, at [7]-[8].

150 Office of the United Nations High Commissioner for Human Rights, above n 117, at [18].

151 Nowak, above n 26, at 66.

152 Human Rights Committee William Eduardo Delgado Paez v Colombia CCPR/C/39/D/195/1985 (1990). See $R v N(1999) 16$ CRNZ 415 (CA) at [9]-[13].

153 Human Rights Committee, above n 152, at [5.5]. 
stance on states' duty to protect against private violations of rights. States can have some level of culpability even when they did not perform the act in question.

(c) ECtHR jurisprudence

The ECtHR has found a wide range of positive obligations beyond those expressly stated in the ECHR. ${ }^{154} \mathrm{~A}$ key case is $X$ and $Y v$ The Netherlands which concerned the right to respect for private and family life. ${ }^{155}$ The objective of that right is to prevent "arbitrary interference by the public authorities". However, the Court held that the state must also secure the right in the private sphere. How this is to be done depends on the aspect of private life in question. ${ }^{156}$ This case specifically required criminal law because it concerned sexual assault. ${ }^{157} A v$ The United Kingdom concerned the right not to be subjected to torture. ${ }^{158}$ The failure to convict A's abusive stepfather violated the judiciary's obligations to protect A. ${ }^{159}$ The obligation to protect applied despite the ill-treatment being a private act. Here, the effective deterrence standard required criminal provisions. ${ }^{160}$ The ECHR's negatively framed slavery provision also imposes positive obligations. $C N v U K$ is an example of this, as is Siliadin where an immigrant to France was held in debt bondage as a domestic servant. ${ }^{161}$ In both cases legislation criminalising conduct commonly occurring alongside servitude was insufficient - the specific act of servitude needed criminalising. ${ }^{162}$

(d) Other jurisdictions

(i) United Kingdom

$C N \vee U K$ indicated that the United Kingdom's protections regarding slavery were insufficient. This section will look at how the United Kingdom has dealt generally with the concept of positive obligations.

The Human Rights Act 1998 (UK) (HRA) incorporates the ECHR into domestic law. It excludes both Houses of Parliament from the scope of public authority. Furthermore, it explicitly states that a

154 Alastair Mowbray "The European Convention on Human Rights" in Mashood A Baderin and Manisuli Ssenyonjo (eds) International Human Rights Law: Six Decades after the UDHR and Beyond (Ashgate, Farnham, 2010) 271 at 286.

$155 X$ and $Y v$ The Netherlands, above n 118, at [18].

156 At [23]-[24].

157 At [27].

158 A v The United Kingdom (1999) 27 EHRR 611 (ECHR) at [19].

159 At [9]-[11] and [23]-[24].

160 Mowbray, above n 115, at 44.

161 Siliadin v France, above n 20, at [9]-[18].

162 At [142] and [145]. 
failure to introduce a proposal for legislation is not subject to the HRA. ${ }^{163}$ If legislation cannot be interpreted consistently with the ECHR then courts will declare it incompatible but must still give it full effect. ${ }^{164}$ There is reasonable consensus in the United Kingdom that the HRA applies to judicial decisions regarding private situations. The dissent arises as to whether courts are obligated to develop the common law in a way that implements ECHR rights. ${ }^{165}$ While there is some horizontal application of rights, it is said that there is not full horizontality which would require courts to create rights and remedies by developing the common law. ${ }^{166}$

In Douglas v Hello! Ltd, the Court of Appeal moved towards protection of privacy although it was not made out in this case. The courts' need to have particular regard for freedom of expression means it is relevant to private situations as a liberty though not an action itself. ${ }^{167}$ Courts have subsequently provided some protection for privacy through expanding breach of confidence. ${ }^{168}$ It is unclear whether this is an incremental development or the creation of an entirely new cause of action. ${ }^{169}$ However, it does indicate a willingness to protect rights in the private sphere even when they are not directly protected in the human rights legislation.

In Venables v News Groups Newspapers, the High Court granted a worldwide injunction to protect the identities of two murderers. This departed significantly from the traditional scope of similar injunctions. ${ }^{170}$ Butler-Sloss J said that judicial actions must be ECHR compliant. Therefore the Court was obligated to protect the murderers from threats to their lives and so ordered the concealment of their identity. ${ }^{171}$ This is an example of the judiciary taking action to protect rights in the private sphere where the existing legal protections are inadequate.

(ii) Canada

Canada has been more reluctant to expand the scope of state responsibility. In Dunmore $v$ Ontario, the Supreme Court of Canada (SCC) held that the Government had to take positive action

163 Human Rights Act 1998 (UK), ss 6(1)(3) and 6(1)(6).

164 Section 4.

165 Hunt, above n 93, at 76-77.

166 At 80; and Ian Leigh "The UK's Human Rights Act 1998: An Early Assessment" in Grant Huscroft and Paul Rishworth (eds) Litigating Rights: Perspectives from Domestic and International Law (Hart Publishing, Portland, 2002) 323 at 337-339.

167 Douglas v Hello! Ltd [2001] QB 967 (CA) at 997, 1001, 1007 and 1012; and Human Rights Act 1998 (UK), s 12(4).

168 Venables v News Group Newspapers [2001] Fam 430; and Leigh, above n 166, at 340.

169 See generally Hunt, above n 93, at 81-82.

170 Leigh, above n 166, at 340.

171 Venables v News Group Newspapers, above n 168, at 467, 468 and 470. 
to guarantee freedom of association. ${ }^{172}$ The legislature had protected that right for all other workers except farm workers. ${ }^{173}$ The SCC said that "without the coercion of legislation" private employers would almost certainly breach the right. ${ }^{174}$ The state's inaction was sufficiently linked to the violation of the right so it was obligated to improve the legislation. ${ }^{175}$ However, the SCC said that there was no general "constitutional right to protective legislation per se"; it was limited to that particular context. ${ }^{176} \mathrm{~A}$ more recent decision - Gosselin v Quebec - concerned the provision of welfare to citizens. The SCC decided that the right to security did not obligate the state to provide its citizens with welfare. They did not rule it out as a possible future development but said the facts of this case were an inappropriate basis. ${ }^{177}$

\section{(iii) Germany}

In Germany, the values contained in the Basic Law guide the three branches of government's use of all areas of law, including private law. This is primarily a result of the Lüth case which concerned a violation of freedom of speech by a private individual. ${ }^{178}$ Judges are bound to adhere to the basic rights when applying private law. Furthermore, some basic rights can only be protected through state action which the state is thus obligated to take. ${ }^{179}$ For example, the state is obligated to provide citizens with social welfare. In contrast to the Canadian position, the Federal Constitutional Court read in positive social rights through the right to human dignity and the principle of the social state. ${ }^{180}$ This sort of wide interpretation of rights could be used as a model for developing protections of slavery.

172 Dunmore v Ontario (Attorney-General) [2001] 3 SCR 1016 at [26].

173 At [3]-[4].

174 Paul Rishworth and others The New Zealand Bill of Rights (Oxford University Press, Oxford, 2003 ) at 59.

175 Dunmore v Ontario, above n 172, at [26].

176 At [20] and [36].

177 Gosselin v Quebec (Attorney-General) [2002] 4 SCR 429 at [81]-[83].

178 Lüth, above n 89, at 205-207; and Donald P Kommers The Constitutional Jurisprudence of the Federal Republic of Germany (Duke University Press, Durham, 1989) at 376.

179 Sabine Michalowski and Lorna Woods German Constitutional Law: The protection of civil liberties (Dartmouth/Ashgate, Hampshire, 1999) at 74 and 77.

180 Schwebel, above n 90, at 1902; and art 1(1) GG (German Basic Law). 
(iv) India

The Constitution of India contains both fundamental rights and directive principles of state policy. The fundamental rights are mostly negative rights and are enforceable. ${ }^{181}$ The directive principles are unenforceable and primarily concern social and economic rights. ${ }^{182}$ However, the fundamental rights mean very little if the socioeconomic environment of India remains unchanged. Using the directive principles to interpret the fundamental rights widely has resulted in positive obligations upon the state. ${ }^{183}$ For instance, the right to life has been combined with the principle of improving public health to obligate the state to provide medical facilities. ${ }^{184}$

(e) Further arguments

The Bill of Rights was specifically drafted to apply only to state and public functions. ${ }^{185}$ It may therefore be contrary to Parliament's original intentions to read in positive obligations. In fact, the White Paper explicitly stated that the Bill of Rights does not impose positive obligations on the state. ${ }^{186}$ Furthermore, the implementation of the ICCPR in New Zealand is not exclusively dependent upon the Bill of Rights. Thus the existence of positive obligations under ICCPR does not necessarily imply the same under the Bill of Rights. ${ }^{187}$

There are several practical difficulties with finding positive obligations under the Bill of Rights. First, our legal system has multiple sources of law. Determining whether the omission to protect a right is a legislative oversight or a gap in the common law can make it difficult to attribute responsibility. ${ }^{188}$ Second, it is unclear whether omissions to regulate can fall within s 3. Omissions can constitute acts done but the omission to regulate is of a different nature being so closely tied to governmental policies. ${ }^{189}$ The Bill of Rights must be enforceable by the courts. This becomes

181 NR Madhava Menon "Constitutional Governance and Economic-Social Rights" in KP Saksena (ed) Human Rights and the Constitution: Vision and the Reality (Gyan Publishing House, New Delhi, 2003) 97 at 103 ; and Constitution of India 1950.

182 Sujata V Manohar "Human Rights and the Constitution: An Overview" in KP Saksena (ed) Human Rights and the Constitution: Vision and the Reality (Gyan Publishing House, New Delhi, 2003) 28 at 30-31.

183 KP Saksena "Introduction" in KP Saksena (ed) Human Rights and the Constitution: Vision and the Reality (Gyan Publishing House, New Delhi, 2003) 11 at 16.

184 Paschim Banga Khet Mazdoor Samiti v State of West Bengal (1996) 4 SCC 37 (India) at [9].

185 New Zealand Bill of Rights Act 1990, s 3; and Butler and Butler, above n 73, at [5.2.11].

186 Palmer, above n 69, at [10.179].

187 See Rishworth and others, above n 174, at 61-62.

188 Butler and Butler, above n 73, at [5.8.18].

189 At [5.2.10]; and Stemplewitz, above n 95, at 17. 
difficult if courts are required to pass judgment on government policy decisions. ${ }^{190}$ That would be contrary to the separation of powers.

Third, bringing human rights rules into areas of private law will introduce greater uncertainty and undermine the autonomy of parties. ${ }^{191}$ The lack of clear-cut and certain definitions in ss 98 and 98AA is emblematic of the difficulty of transplanting human rights law into domestic criminal law. Human rights law applies to the state, aims at protecting society and developing systems, and therefore uses expansive interpretations. Criminal law focuses on individual culpability which requires precise definitions to provide certainty and predictability. ${ }^{192}$ Fourthly, positive obligations involve an even greater shift of power from Parliament to the judiciary. This was always a concern regarding the Bill of Rights, even without positive obligations. ${ }^{193}$ With positive obligations the judiciary would be far more active in remedying legislative omissions and generally making law.

However, this recent trend of positive obligations is necessary. International expectation is that the protection of human rights is prioritised. ${ }^{194}$ Privatisation has seen many traditional state functions delegated to private actors. ${ }^{195}$ There are also a number of human rights, such as slavery, which are primarily violated by private parties, not states. ${ }^{196}$ Most societies are increasingly stateregulated such that most private interactions have some public aspect. ${ }^{197}$

The long title of the Bill of Rights is similar to the general provisions of the ICCPR and ECHR. Interpreting it in light of those treaties thus suggests that it too gives rise to positive obligations. Arguably, incorporating rights into a single, constitutional instrument sufficiently promotes human rights principles without requiring further obligations. ${ }^{198}$ However, increasingly it has been realised that merely preventing state violations does not adequately protect rights. Individuals are very capable of violating human rights. Effective human rights protection therefore involves the regulation and education of individuals. ${ }^{199}$ Jeremy Waldron has explained this as there being waves

190 Palmer, above n 69, at [10.179]. See generally Clark v Governor-General, above n 134, at [61] and [62].

191 Leigh, above n 166, at 339.

192 Vladislava Stoyanova "Article 4 of the ECHR and the Obligation of Criminalising Slavery, Servitude, Forced Labour and Human Trafficking" (2014) 3 CJICL 407 at 418 and 420.

193 Palmer, above n 69, at [6.2]-[6.21].

194 Siliadin v France, above n 20, at [148].

195 August Reinisch "The Changing International Legal Framework for Dealing With Non-State Actors" in Philip Alston (ed) Non-State Actors and Human Rights (Oxford University Press, Oxford, 2005) 37 at 81.

196 Nowak, above n 26, at 195-196.

197 Stemplewitz, above n 95, at 6.

198 At 26

199 Clapham, above n 94, at 126. 
of duties on the state. The first wave is not to enslave people but the second wave is to educate about what constitutes slavery whilst another wave is to remedy situations where slavery is likely to occur. $^{200}$

Furthermore, many of the traditional dividing lines applied to human rights now primarily create shields behind which human rights violations more easily occur. The distinction between active and permissive legislation is one such distinction. ${ }^{201}$ Another is the use of a public-private divide. ${ }^{202}$ The threshold for what constitutes public behaviour varies between states. Therefore using that distinction to determine what constitutes a human rights violation may result in overly strict protection in some states and lacunae in others. ${ }^{203}$ In addition, rhetoric about positive and negative rights is increasingly being replaced with the idea that all rights have a positive element. ${ }^{204}$

\section{(f) In summary}

Reading in positive obligations is a key part of modern human rights jurisprudence around the world and is accepted by academic commentary. The HRC's conclusive statements about positive obligations and the open door left by domestic courts suggest that the Bill of Rights should be read as imposing positive obligations on the state actively to protect human rights. Whilst there are certainly cogent practical reasons against that, the importance of protecting human rights in today's world outweighs them. New Zealand is hence positively obligated to protect against slavery. Yet as discussed above the current measures in place do not meet the necessary standard.

\section{A TORT ACTION}

As discussed in Part VII, one response of the courts implicated by Drittwirkung to the inadequate legal protection of slavery victims is the development of a tort specifically addressing slavery. The need to fill the gap is further supported by the existence of positive obligations. A claim in tort is advantageous for the compensation, vindication and deterrence it offers. ${ }^{205}$ The privacy tort was recently created by reading privacy into the Bill of Rights. It is useful in consideration of a tort for slavery to look at the creation of this privacy tort.

200 Jeremy Waldron "Rights in Conflict" in Jeremy Waldron (ed) Liberal Rights: Collected Papers 1981-1991 (Cambridge University Press, Cambridge, 1993) 203 at 212.

201 Clapham, above n 94, at 189.

202 At 343.

203 At $127-128$.

204 Hunt, above n 93, at 77 and 83.

205 Stewart, above n 61, at 907. 
Despite the exclusion of privacy from the Bill of Rights and the previous absence of a tort, it was an important common law value. ${ }^{206}$ Hence the authoritative declaration of a privacy of information tort in Hosking was preceded by years of contemplation. Parliament had already provided a number of protections for privacy and some argued that the courts should not extend the law further. ${ }^{207}$ However, Tipping J responded that: ${ }^{208}$

If Parliament wishes a particular field to be covered entirely by an enactment, and to otherwise be a no-

go area for the Courts, it would need to make the restriction clear.

Furthermore, Gault $\mathrm{P}$ and Blanchard $\mathrm{J}$ considered the development of a privacy tort consistent with, not precluded by the statutory developments. ${ }^{209}$ Any common law development regarding slavery would need to be consistent with existing statutory measures. In 2012, the High Court also introduced a privacy tort of intrusion upon seclusion. ${ }^{210}$ These privacy torts are still relatively new and very uncertain. Nonetheless they exemplify the courts' willingness to develop the common law in response to the increasing importance of privacy both domestically and internationally.

Reading in rights requires some level of judicial activism. However, a number of the key arguments against the privacy tort do not apply to slavery. In that respect, there is a stronger argument for a slavery tort than there was for a privacy tort. Privacy is a relatively wide and uncertain legal concept. ${ }^{211}$ It has only recently developed due to greater concern with rights, increased prominence of the value of individuals and modern accessibility of information. ${ }^{212}$ Comparatively, slavery is a narrower, older and more certain concept than privacy with more universal condemnation. Privacy is absent from the Bill of Rights and its existence significantly restricts the right to freedom of expression. ${ }^{213}$ Slavery is likewise absent. However, protection against slavery does not involve direct balancing against any other rights.

In the United Kingdom, breach of confidence was expanded to include privacy. In contrast to this, New Zealand privacy is a newly created, separate tort. It does, however, bear resemblance to breach of confidence. ${ }^{214}$ The courts' experience in dealing with this similar concept and the

206 Todd, above n 61, at [17.2] and [17.3].

207 At [17.4.01]-[17.4.02]. See generally Crimes Act 1961, s 216H; Search and Surveillance Act 2012, s 46; Residential Tenancies Act 1986, s 38; and Broadcasting Act 1989, s 4(1)(c).

208 Hosking $v$ Runting, above n 76, at [228] per Tipping J.

209 At [92], [96] and [108].

210 C v Holland, above n 76, at [86]. See generally Todd, above n 61, at [17.6].

211 Todd, above n 61, at [17.1] and [17.4.02].

212 At [17.3]

213 At [17.4.02]; and New Zealand Bill of Rights Act 1990, s 14.

214 See $C v$ Holland, above n 76, at [52]. 
extensive prior contemplation of a privacy tort perhaps made its introduction an easier step. It is a fine line whether this was a development of the common law consistent with the Drittwirkung concept or the introduction of a completely new tort to satisfy positive obligations. ${ }^{215}$ However, the New Zealand courts preferred to treat privacy separately from breach of confidence because they considered them two distinct concepts. ${ }^{216}$ This reasoning could be similarly used to support treating slavery separately from the torts mentioned in Part IV.

The development of a tort of slavery would significantly improve the protection offered against slavery in New Zealand. The courts would be able to incorporate into it the idea of ownership and use the International Labour Organization indicators to effectively identify slavery situations. Given the positive obligations to protect against slavery this is an improvement that ought to be made.

\section{CONCLUSION}

New Zealand has some legal measures in place to prevent and prosecute slavery. Unfortunately these measures do not address the issue at the heart of slavery - ownership of another human being. The Bill of Rights can be used to read these provisions widely but even this is not enough to provide comprehensive protection.

Fortunately, the traditional focus of human rights on preventing state action is being supplemented with the idea of Drittwirkung and positive obligations. States must actively ensure thorough protection against rights violations including those committed by private individuals. In $C N \vee U K$, the ECtHR imposed these obligations upon the United Kingdom. The narrow framing of the existing legislation had left the applicant, a victim of domestic servitude, without remedy. Despite the ECHR slavery provision being negatively framed, the United Kingdom was obligated to take positive action to prevent and prosecute slavery.

New Zealand needs to recognise slavery as a high-priority issue. Specific attention needs to be directed towards improving the protection offered so that there is no gap through which slavery can escape without consequences. The development of a tort action dealing with slavery is something that should be considered by the courts. This would provide an action especially designed to combat slavery. The application of Drittwirkung and New Zealand's positive obligations necessitate nothing less. William Wilberforce's statement ought to be heeded; New Zealand must not look the other way. $^{217}$

215 See Leigh, above n 166, at 337-339.

216 Todd, above n 61, at [17.5.05].

217 Walk Free Foundation, above n 1, at 4. 